\title{
Ecology of soil arthropod fauna in tropical forests: A review of studies from Puerto Rico ${ }^{1}$
}

\author{
Grizelle González $z^{2 *}$ and María Fernanda Barberena-Arias ${ }^{3}$
}

J. Agric. Univ. P.R. 101:185-201 (2017)

\begin{abstract}
The majority of ecological studies in the tropics deal with organisms participating in grazing food webs, while few deal with the diversity of invertebrates in the soil, leaf litter or dead wood that participate in detrital food webs. For tropical forests, the status of information on soil animal diversity is limited, especially when compared to other ecosystems such as temperate forests, grasslands, and deserts. Given the high rate of forest conversion and persistence of deforestation in the tropics, it is important to study the diversity of its fauna and assess how global changes will affect the linkages between soil biota and ecosystem functioning. This review article focuses on surveys and studies conducted in Puerto Rico, a tropical Caribbean island where a significant number of ecological investigations have focused on the characterization of the edaphic fauna, and how they influence ecosystem processes in forested sites. Results from experimentations suggest that soil fauna is an important determinant of decay and nutrient cycling in these forests. Likewise, this article highlights the importance of methodological constraints in studies that compare these organisms at sites with differing climatic conditions, and focuses on the description of ecological studies related to the effects of microarthropods on litter and wood decay.
\end{abstract}

Key words: litter invertebrates, microarthropods, Puerto Rico, soil ecology, tropics

\section{RESUMEN}

Ecología de la fauna de artrópodos de suelo en bosques tropicales: Una revisión de estudios de Puerto Rico

La mayoría de los estudios ecológicos en áreas tropicales se centran en organismos que participan en redes tróficas de pastoreo, mientras que pocos se han enfocado en la diversidad de invertebrados en el suelo, hojarasca o madera muerta que participan de redes tróficas de detrito. En los bosques tropicales, el estado de información sobre la diversidad de animales del suelo es limitado, especialmente cuando se compara con otros ecosistemas tales como bosques templados, praderas y desiertos. Dada la

${ }^{1}$ Presented at Entomology Symposium: Legacy of the International Institute of Tropical Forestry (IITF) 75th Anniversary, March 17-18, 2017, San Juan, P.R.

${ }^{2}$ USDA Forest Service, International Institute of Tropical Forestry, Jardín Botánico Sur, 1201 Ceiba St., Río Piedras, Puerto Rico, 00926, Puerto Rico; ggonzalez@fs.fed.us. *Corresponding author.

${ }^{3}$ School of Natural Sciences and Technology, University of Turabo, PO Box 3030, Gurabo, Puerto Rico 00778. 


\begin{abstract}
alta tasa de conversión forestal y la persistencia de la deforestación en los trópicos, es importante estudiar la diversidad de su fauna y evaluar cómo los cambios globales afectarán los vínculos entre la biota del suelo y el funcionamiento del ecosistema. Este artículo de revisión se centra en censos de biodiversidad y estudios realizados en Puerto Rico, una isla tropical caribeña donde un número significativo de investigaciones ecológicas se han centrado en la caracterización de la fauna edáfica y cómo influyen en los procesos de los ecosistemas en áreas boscosas. Los resultados de las experimentaciones sugieren que la fauna del suelo es un determinante importante de la descomposición y del ciclo de nutrientes en estos bosques. Asimismo, este artículo resalta la importancia de las limitaciones metodológicas en estudios que comparan estos organismos en sitios con diferentes condiciones climáticas, y se centra en la descripción de estudios ecológicos relacionados con los efectos de los microartrópodos sobre la hojarasca y la descomposición de la madera.
\end{abstract}

Palabras clave: ecología de suelo, invertebrados de hojarasca, microartrópodos, Puerto Rico, trópico

\title{
INTRODUCTION
}

Soil and litter microarthropods (invertebrates with segmented bodies, chitinous exoskeleton and jointed legs) are essential components of ecosystems, influencing decomposition and nutrient cycling. They range in size from microscopic $(100 \mu \mathrm{m})$ to relative macro extents (over $20 \mathrm{~mm}$ ) in terms of body width (Swift et al., 1979), and encompass a diverse group of animals including Insecta (such as springtails, beetles, termites and ants); Crustacea (e.g., sowbugs); Chelicerata (e.g., spiders, mites, pseudoscorpions and scorpions); Myriapoda (centipedes and millipedes); proturans; and diplurans among others. Microarthropods occupy all trophic levels within the detritivore food web (Seastedt 1984) and undertake beneficial functions in the soil-plant system by increasing the surface area of organic materials, stimulating microbial activity, mixing microbes within the soil/litter environment, changing the physical properties of soils (including porosity, water-infiltration rate, and bulk density) by burrowing, and helping mineralize nutrients for plant growth.

Despite the positive effects that microarthropods can have on terrestrial ecosystems, it is not yet fully understood how their communities are structured and how environmental variables influence this structure. In the tropics, a great deal of attention has been given to aboveground organisms, while few studies deal with the diversity of invertebrates in the soil, leaf litter, or dead wood (Wall et al., 2011). For tropical forests, the status of information on soil animal diversity is limited particularly when compared to other ecosystems such as temperate forests, grasslands and deserts. Given the high rate of forest conversion and the persistence of deforestation in the tropics, it is im- 
portant to study the diversity of its fauna and assess how these global changes will affect the linkages of soil biota and ecosystem functioning. Both non-anthropogenic and anthropogenic disturbances may increase nutrient losses from tropical forests depending on how the debris is managed, and how the soil organisms respond to the disturbance and the chemical and physical characteristics of the soil and litter.

To further understand the dynamics and influences of soil biota in tropical environments, we include surveys and studies of soil and litter microarthopods conducted in Puerto Rico, a tropical Caribbean island, where both non-anthropogenic and anthropogenic disturbances are central to shaping its landscape and biota, and where a significant number of ecological investigations have centered on the characterization of the edaphic fauna and how they influence ecosystem processes in forested sites. In the following sections, we summarize findings of studies on the abundance and diversity of microarthropods in various forest types across the island, highlight the importance of methodological constraints in the study of these organisms at sites with differing climatic conditions, review ecological studies focused on the effects of microarthropods on litter and wood decay, and finalize with some insights about the implications of soil biodiversity to ecosystem functioning in the context of a dynamic and complex tropical landscape.

\section{STUDIES OF MICROARTHROPOD DYNAMICS IN PUERTO RICO'S FORESTS}

In Puerto Rico, deforestation occurred extensively during the 19 th century. Much of the land was dedicated to agricultural use, and only 12 percent remained as forested lands or as shaded coffee plantations (Franco et al., 1997). Towards the end of the 20th century, the forested area increased up to 35 to 42 percent mainly due to the transition from an agrarian to an industrialized society (Birdsey and Weaver, 1987; Franco et al., 1997; Helmer et al., 2002). Agricultural abandonment and development continued to increase, as indicated in the maps by Gould et al. (2008) showing that woody vegetation cover had increased to more than 50 percent of the island. While most of the abandoned lands were not managed, invasion and natural regeneration of tree species have reverted many of the cattle pastures to secondary forests (Zou and González, 1997). This rehabilitation process has proven useful to study changes in the density and community structure of soil biota and ecosystem functioning (e.g., Zou and González, 1997; González et al., 1996; González and Zou, 1999; Barberena-Arias and Aide, 2003; Huang et al., 2006; Sánchez-de León and Zou, 2004; Huang et al., 2016) - as described for microarthropods in the following paragraphs. 
Moist secondary forests. Barberena-Arias and Aide (2003) and Osorio-Pérez et al., (2007), respectively, studied the species diversity and trophic composition of litter insects including ants. They found that arthropod species richness increases during plant secondary succession as few arthropod species occur in early successional habitats ( $\sim 5 \mathrm{yr}$ since abandonment) while higher numbers of arthropod species occur in intermediate and late successional forests ( $>25 \mathrm{yr}$ since abandonment) (Figure 1). These authors found the arthropod species composition was significantly different between early and intermediate/late forests suggesting that early successional habitats have few species that are unique, and intermediate/late habitats have more species that are specific to woody habitats. During secondary succession, forests change from shrub-dominated habitats in early succession to tree-dominated habitats in intermediate/late successional forests. The increase in arthropod richness and the change in arthropod composition between early and intermediate/late forests probably is the result of a change in habitat physical-chemical characteristics (e.g., temperature and humidity) and the kinds of resources used by arthropods (e.g., wood, leaves) (Murdoch et al., 1972).

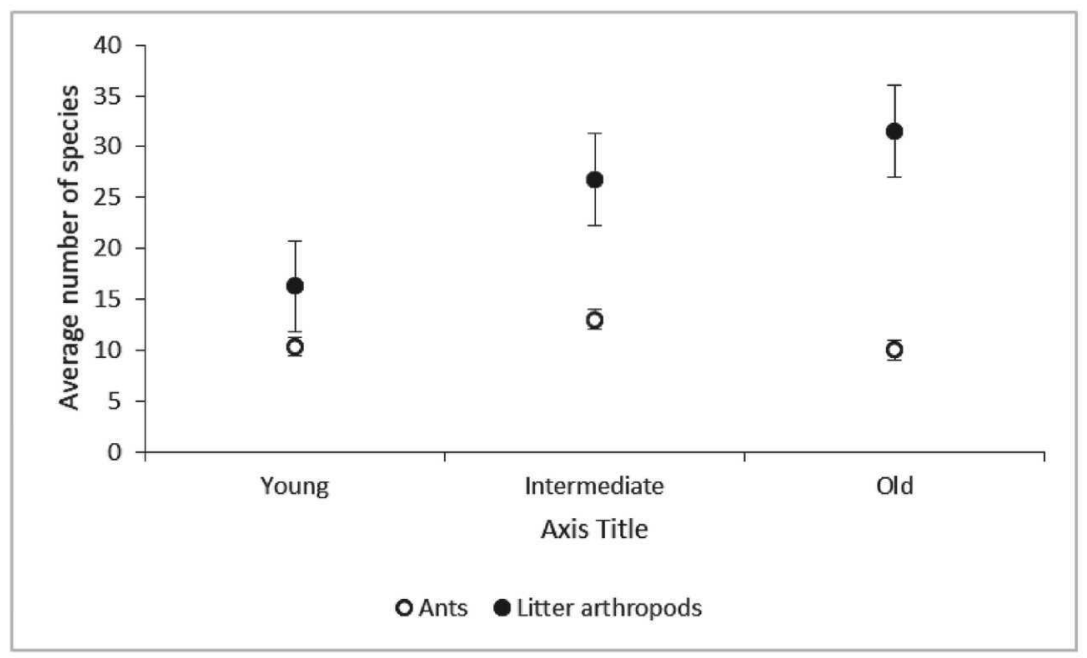

FIGURE 1. Average richness $(\overline{\mathrm{x}} \pm \mathrm{sd})$ of ants and other litter arthropods in sequential successional secondary forests in moist regions of Puerto Rico. Young forests correspond to habitats that have been abandoned for ca. $5 \mathrm{yr}$; intermediate forests correspond to habitats that have been abandoned for ca. $30 \mathrm{yr}$; and old forests correspond to habitats that have been abandoned for $>80 \mathrm{yr}$. Data for ants are from Osorio-Pérez et al. (2007), and data for litter arthropods are from Barberena-Arias and Aide (2003). 
The trend in arthropod recovery during plant secondary succession may be altered when forests are dominated by single tree species, as found in monospecific stands, and when disturbances occur. When comparing arthropod richness between pastures and forests, Barberena et al. (2012b) found that arthropod richness was higher in pastures than in monospecific forests of Spathodea campanulata. Nevertheless, when comparing pastures to forests where $S$. campanulata co-occur with native tree species, arthropod species richness was higher in forests than in pastures. These results suggest that the recovery of arthropod diversity during plant secondary succession is dependent not only on the increase of wood and concomitant resources but also on the recovery of plant diversity. Arthropod recovery may also change in response to disturbances such as hurricanes that change habitat characteristics and the amount and distribution of biomass that resulted in an increased arthropod richness and a different arthropod community in early successional habitats (Barberena-Arias and Aide, 2002).

Dry forests. In general, there are few studies on soil faunal diversity and ecosystem functioning in dry tropical forests compared to wet tropical forests (Wall et al., 2011). Reasons for this bias include an emphasis on wet forests due to the high biodiversity and rapid deforestation, and poor recognition of ecosystem services that soil biota provide to humans (See Wall et al., 2011 for referencing; Table 1). In Puerto Rico, about eight percent of the land is composed of dry woody vegetation. The effect of plant diversity on arthropods is also found in

TABLE 1.-Ecosystem goods or services, processes involved, and estimated contribution of faunal diversity in dry tropical forests (from Wall et al., 2011).

\begin{tabular}{|c|c|c|}
\hline Good or service provided for humans & Ecosystem process & $\begin{array}{c}\text { Relative } \\
\text { contribution of } \\
\text { faunal biodiversity }\end{array}$ \\
\hline Food production & $\begin{array}{l}\text { Bioturbation, wood decom- } \\
\text { position }\end{array}$ & Small \\
\hline Water quality & $\begin{array}{l}\text { N-retention in biomass, } \\
\text { physical stabilization, in- } \\
\text { terception of runoff }\end{array}$ & Large \\
\hline Watershed flow & $\begin{array}{l}\text { Moisture retention by or- } \\
\text { ganic matter, evapotrans- } \\
\text { piration }\end{array}$ & Medium to small \\
\hline Fiber production & $\begin{array}{l}\text { Decomposition, organic } \\
\text { matter/nutrient cycling, } \\
\text { nutrient availability, N- } \\
\text { fixation }\end{array}$ & Large \\
\hline C sequestration & $\begin{array}{l}\text { Organic matter formation, } \\
\text { inorganic } \mathrm{C} \text { deposition }\end{array}$ & Large \\
\hline Trace gas regulation & $\begin{array}{l}\text { Maintenance of } \mathrm{C} \text { and } \mathrm{N} \\
\text { balances }\end{array}$ & Large \\
\hline
\end{tabular}


dry forests on the island. For example, on Mona Island litter arthropod species richness was highest in the coastal forest when compared to the plateau forest and the mahogany monospecific stand, while species composition was consistent in the plateau forest and monospecific stand and highly variable in the coastal forest (Barberena-Arias, 2000). Warren (2000) described these three habitats as being along a continuum with the coastal forest on one side with high stem density and evenly abundant plant species, and the mahogany monospecific stand on the other side with less stem density and higher species dominance (i.e., mahogany). As a consequence, the highest arthropod richness found in the coastal forest is associated with higher plant species diversity, while the reduced richness found in mahogany is associated with the dominance of a plant species.

On a lower spatial scale, litter arthropods are also affected by the area of influence of specific plant species. In Guánica (a dry forest reserve), Barberena-Arias (2008) studied single tree species effects on temperature, nutrients and arthropod diversity in litter and humus layers and found arthropod richness was higher under deciduous plant species when compared to evergreen species (Barberena-Arias, 2008). During the dry season, deciduous Ficus citrifolia and Pisonia albida drop their leaves while evergreen Coccoloba uvifera and Conocarpus erectus retain the leaves. Both are plant strategies to deal with water scarcity either by having no leaves or by having tough succulent leaves. Higher arthropod richness found under deciduous species is associated with annual pulses of high quality litter. On the other hand, the low arthropod richness found under evergreen tree species is associated with year-round deposition of low quality litter (Figure 2). Also, Barberena-Arias (2008) found that arthropod species composition was similar under Ficus and Pisonia, and unique under Conocarpus and unique under Coccoloba. These results suggest that evergreens produce low quality litter that promotes the occurrence of specialized arthropods resulting in unique arthropod assemblages associated with low quality litter. On the other hand, deciduous plants produce high quality litter that promotes the occurrence of common shared arthropods resulting in the homogenization of arthropod assemblages associated with high quality litter.

Humid forests. Most of the studies of soil and litter arthropods in wet forests in Puerto Rico have been performed in the Luquillo Mountains. Odum et al. (1970) and Pfeiffer (1996) studied faunal inventories at El Verde Field Station and found that about half of the total faunal biomass was concentrated in the top thin layer of soil and litter. Many studies at El Verde have demonstrated that mites are the most dominant taxon in the litter layer of the tabonuco forest $(>1,500$ ) 


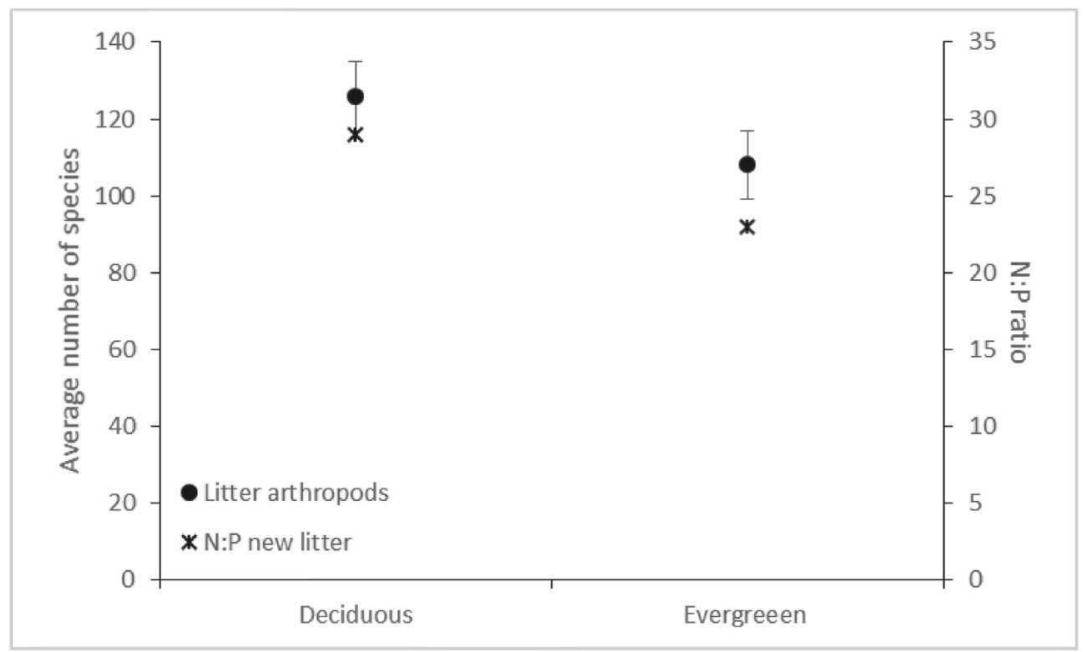

FIGURe 2. Average richness $(\overline{\mathrm{x}} \pm \mathrm{sd})$ of litter arthropods and $\mathrm{N}: \mathrm{P}$ ratio in new (i.e., recently fallen) litter $(\overline{\mathrm{x}})$ in deciduous and evergreen tree species in the Guánica Dry Forest. Deciduous species are Ficus citrifolia and Pisonia albida; evergreen species are Coccoloba uvifera and Conocarpus erectus. Data are from Barberena-Arias (2008).

$\mathrm{m}^{2}$ ) (Pfeiffer, 1996; González and Seastedt, 2000; Richardson et al., 2005; Richardson et al., 2010; Richardson and Richardson, 2013) although they account for less than one percent of the total invertebrate biomass (Richardson et al., 2005). In an effort to relate species richness and abundance of litter-based invertebrate communities to forest productivity along elevational/ecological gradients, Richardson et al. (2005) compared mixed forest stands with adjacent areas under palm vegetation at different elevations within the Luquillo Mountains. In forest floor litter communities, using palm litter as a control for forest type, they found that although overall net primary productivity (NPP) declined with increasing elevation and rainfall, animal abundance, biomass, and species richness were remarkably similar along the gradient. In non-palm litter, all community parameters declined with increasing elevation, along with NPP and litter nutrient concentrations (Richardson and Richardson, 2013). As a consequence, they concluded that differences observed in animal abundance and species richness, and the uniformity of communities along the increasing elevational gradient were better explained by the contribution of forest composition to the chemical and physical nature of litter and forest heterogeneity, rather than to direct effects of temperature and rainfall differences (Richardson et al., 2005). Patterns found by González 
and Murphy (unpublished data) in microarthropod communities (both surface-active and soil dwelling) in eight forest types along an elevational gradient in northeastern Puerto Rico are consistent with those of Richardson and Richardson (2013). Using an ordination, González and Murphy (unpublished data) found that in general, surface-active communities were mostly influenced by the canopy cover and litter chemistry, while soil dwelling communities were influenced by canopy cover and soil chemistry. Factors such as elevation (and their temperature and precipitation correlates) also influenced these microarthropod communities, but not as strongly as did the microclimate and chemistry variables (Figure 3 ).

The density of macroarthropods (such as myriapodans and crustaceans) is higher at El Verde than in tropical sites elsewhere; ants are also an important component of the litter invertebrate community with densities ranging from 500 to $1,200 / \mathrm{m}^{2}$ (Pfeiffer, 1996; Richardson et al., 2005). In the Luquillo Mountains, millipedes appear to be the predominant taxa in the tabonuco forest litter in terms of standing

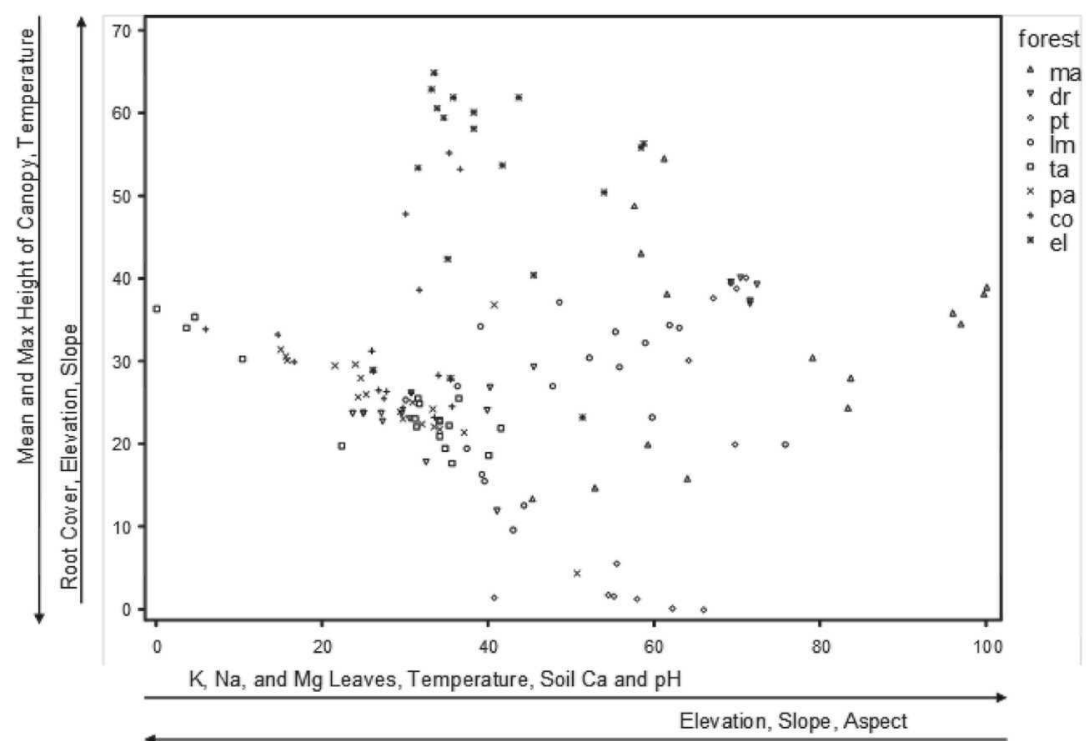

FIguRE 3. Detrended Correspondence Analysis (DCA) ordination bi-plot of the biomass of surface active microarthropods along an elevational gradient in northeastern Puerto Rico (González and Murphy, unpublished data). The legend refers to: mangroves (ma), dry (dr), Pterocarpus (pt), lowland moist ( $(\mathrm{m})$, tabonuco (ta), palm (pa), palo colorado (co) and elfin (el) forests. The arrows indicate the environmental variables correlated with each axis; the direction of arrows shows if it is a positive or negative relationship. 
stocks (0.6 g/m²; Pfeiffer, 1996). Richardson et al. (2005, pers. com.) found that at El Verde, diplopods represented about 11.4 percent (73.09 $\mathrm{mg} \mathrm{dry} / \mathrm{m}^{2}$ ) of the total microarthropod biomass, second only to Isoptera. Murphy et al. (2008) studied millipede biomass, abundance and richness in different vertical ground layers (litter, humus, 0 - to 5 -cm soil depth, and 5- to 10-cm soil depth) and across topographic positions (i.e., slopes, valleys and ridges), in the tabonuco forest at El Verde. Overall they found four orders: Stemmiulida (the most abundant, ca. 22 individuals per square meter), Glomeridesmida, Spirostreptida, and Polydesmida (the least abundant). Millipede density and the richness of orders varied depending on the topographic position, with ridges having significantly less of both. The ground layer also significantly affected millipede richness but not density, with the humus being the richest layer. Millipede biomass did not significantly differ among the different topographic positions or layers. There was a significant positive correlation between the soil $\mathrm{pH}$ and millipede richness, and between millipede richness and the amount of wood and fruit found in the litter and humus layers. Thus, the results from Murphy et al. (2008) indicate millipedes have higher density and richness in slope and valley topographic positions than in ridges, and in less acidic soils in the tabonuco forest of El Verde.

Working on a broader scale, Galanes and Thomlinson (2011) examined the relationship between soil millipede diversity and landscape structure in northeastern Puerto Rico. They found that millipede species diversity and composition in forest patches were correlated with the patch surroundings (e.g., the amount of forest in the matrix) and with the presence of vegetation corridors that connected to other forest patches, rather than being correlated with forest patch attributes such as patch area and shape. The results of this study show that the number of millipede species in a forest patch is related to the proximity to other forest patches within 600 $\mathrm{m}$, while the relative abundance or evenness of millipede species is related to the percent of forest in the matrix within $50 \mathrm{~m}$. In this study, there was no correlation between patch shape or area and millipede species richness and diversity, indicating that patch area, the amount of patch edge or degree of convolution are not significant factors in determining millipede species diversity, although these factors are significant variables in determining woody plant diversity in these forest patches (Galanes and Thomlinson, 2009; Galanes and Thomlinson, 2011). Galanes and Thomlinson (2011) indicate that it is necessary to maintain forest patches with a low degree of patch isolation, interconnected by vegetation corridors and surrounded by a buffer of vegetation to protect terrestrial organisms such as millipedes that require particular forest resources and microclimatic conditions of temperature and humidity to survive and disperse. 
Methods for estimating arthropod diversity in dry and wet forests in Puerto Rico. Barberena-Arias et al. (2012a) quantified the variation of soil and litter arthropods in tropical dry and wet forests using different sampling protocols to determine whether diversity measures were affected by variations in the collection and extraction methodologies, and the duration of the extraction. They found that conditions within Berlese funnels (used for extraction of arthropods) differentially affected estimates of the diversity of samples from habitats with contrasting environmental conditions. Wet forests receive more precipitation and usually have a closed canopy that reduces the amount of light that reaches the forest ground, reducing temperature but increasing humidity. In contrast, dry forests receive less precipitation and have an open canopy that results in higher temperatures and lower humidity. Barberena-Arias et al. (2012a) found that the light used in Berlese funnels differentially affected arthropods. For example, when using incandescent bulb light, 90\% of litter arthropods from wet forests were collected in the first $48 \mathrm{~h}$ possibly because of an increase in temperature and decreased humidity produced by the light-bulb, while litter arthropods from dry forests, which are better adapted to higher temperatures, took longer to exit the sample. Soil arthropods showed a similar response to light by being more quickly extracted in the presence of light, but total estimates of abundance were highest when no light was used even though the total period of extraction was longer. Results from Barberena-Arias et al. (2012a) indicate that methodology standardization is necessary if we are to compare community composition parameters based on similarly high extraction efficiencies from microarthropod samples collected from sites with differing climatic regimes. In addition, it is important to determine the collection method best suited depending on the environment to be sampled and the focal organism to be studied.

\section{STUDIES OF SOIL FAUNAAND ORGANIC MATTER DECAY IN FORESTED SITES IN PUERTO RICO}

Although decomposition is mainly the result of microbial activities, soil fauna are considered crucial in conditioning the litter and in stimulating microbial actions (Coleman and Crossley, 1996). Soil fauna effects on mineralization processes often seem intuitive because their importance is seldom properly quantified and put in the context of other regulating factors (González, 2002). Complex organismal interactions that vary among ecosystems and organisms of interest, are embedded within the organismal section of the well-accepted three-factor model of organic matter decay sensu Swift et al. (1979) - which also include 
climatic and substrate quality constraints (González, 2002). The range of values for the contribution of soil fauna activities to litter decomposition varies widely along latitudinal gradients, because it depends on the confounding effects of the size, abundance, diversity, and functionality of the fauna (e.g., Hansen, 1999; Heneghan et al., 1999; Irmler, 2000; González and Seastedt, 2001; González 2002).

Leaf litter decay and soil biota. Rates of leaf, wood, and fine root decomposition are rapid in the Luquillo Mountains, as in many other tropical forests (La Caro and Rudd, 1985; Bloomfield et al., 1993; Sullivan et al., 1999; González et al., 2001; Santana et al., 2005). Heneghan et al. $(1998,1999)$ showed that the decomposition of oak litter proceeds faster in Puerto Rican and Costa Rican forests than in a temperate forest in North Carolina. They found microarthropods to have little effect on the decomposition in the temperate forest, whereas their influence was pronounced at the tropical sites, despite similar or even lower species diversity.

Other studies from the tabonuco forest show that although litter chemistry is an important determinant of decay, soil arthropods and earthworms have particularly strong influences on the rates of litter decomposition in the Luquillo Mountains. González and Seastedt (2001) showed soil fauna to be responsible for up to 66 percent of the total decomposition of Cecropia schreberiana leaves. Ruan et al. (2005) found that millipede density explained 40 percent of the variance in leaf litter decomposition rates in this forest. Millipedes are considered to be important organisms involved in decomposition, due to their direct feeding on detritus and their indirect effects on microbial activity (González et al., 2012). To further the understanding of direct (leaf fragmentation) and indirect (microbial biomass) effects of millipedes on the decomposition of leaf litter, González et al. (2012) used a microcosm approach to determine how these variables are influenced by the substrate (litter) quality and the density of millipedes. González et al. (2012) found millipedes can affect leaf litter decomposition both directly and indirectly, but the extent of their effect depends on their density and the quality of the substrate (leaf lignin content). They also found a decrease in soil microbial biomass over time, although microbial biomass was not affected by the presence of millipedes. These results suggest that millipedes are not the only arthropods influencing decomposition in the tabonuco forest and that interactions with other organisms in their natural environment could alter the extent of millipede influence on litter decay. González et al. (2001) found that exclusion of soil fauna in two tropical forests (dry and wet) in Puerto Rico did not affect the biomass and maximum growth rates of microorganisms, suggesting a larger net regulatory effect of soil fauna on microbes 
via indirect mechanisms (e.g., through the modification of the soil and litter environment rather than through direct feeding) in the tropics than in the compared subalpine forests.

In the context of a canopy trimming experiment at El Verde tabonuco forest, Richardson et al. (2010) and González et al. (2014) used litterbags of two different mesh sizes to quantify the effects of different groups of soil fauna on the decay of fresh and senesced leaves. Richardson et al. (2010) found that the relatively smaller $(0.475 \mathrm{~mm})$ mesh sizes (compared to larger openings of $1.8 \mathrm{~mm}$ ) only influenced the abundance and biomass of microarthopods by excluding larger organisms, but did not cause major changes in taxonomic composition. While, in the same experiment, González et al. (2014) found negative correlations between mesh size and percent mass loss, and between the Margalef diversity index for arthropods and percent mass loss, suggesting that functional complexity is an important determinant of decay in this forest.

Herbivore-induced inputs to the forest floor can also affect rates of litter decomposition and nutrient flux from litter to mineral soil in this tropical wet forest. Schowalter et al. (2011) found that herbivory treatments significantly retarded, rather than accelerated, litter decomposition. The findings of this study suggest that herbivore-induced changes in nitrogen fluxes and/or C:N ratios in frass may have been sufficient to influence the microbial processes that regulate the decomposition of leaf litter in this forest - particularly through the inhibited growth of basidiomycete fungi, a primary decomposer in the system (Lodge et al., 2008).

Meanwhile, Yang et al. (2007) looked at fertilization responses of soil litter fauna and litter quantity, quality and turnover in low (wet) and high (elfin) elevation forests of Puerto Rico; they found that in El Verde wet forest, higher quality litter in the fertilized plots did not turn over faster than controls, contrary to expectations. Similar litter turnover rates in control and fertilized plots in the wet (tabonuco) forest, despite increased litter quality, indicate that soil fauna play a larger role in regulating decomposition in the wet rather than high elevation (elfin) forest. Thus, the results from this study of two forest types along an elevational gradient are similar to those reported in latitudinal gradient studies (e.g., Heneghan et al., 1998, 1999; González and Seastedt, 2000).

Decaying wood and soil biota. Decomposer organisms can be key determinants of decay in forest types in northeastern Puerto Rico (e.g., González and Seastedt, 2001). Yet the contribution of different groups of decomposers to the decay of coarse woody debris (CWD) might vary among the different forest types located along elevational and environmental gradients (González and Luce, 2013). For example, González 
and Luce (2013) found in the elfin forest, the decay class of CWD was most strongly correlated with white rot fungi. Yet, across all forest types in this study, the decay class of CWD also correlated well with the average occurrence of brown rot fungi. Decreased decay as mean annual precipitation increases, and differential effects of organisms on decay would be consistent with results previously reported by Torres and González (2005) and González et al. (2008). Torres and González (2005) studied the decomposition of Cyrilla racemiflora logs over a 13yr period in tropical dry and wet forests in Puerto Rico. The mean mass loss, ratio of soft to hard wood, nutrient concentrations, and the diversity of wood-inhabiting organisms were greater in logs decomposing in the dry forest than in the wet forest. Termites were also more abundant in the logs collected from the tropical dry forest than the tropical wet forest. High moisture content and low animal diversity on the logs in the wet forest seem to retard wood decay in this habitat. Wood decay rates in the tropical dry forest can be related to the high diversity of species and functional groups of wood-inhabiting organisms. González et al. (2008) set up a wood decomposition experiment to quantify the percentage of mass remaining, decay constant and performance strength of aspen stakes (Populus tremuloides) in dry and moist boreal (Alaska and Minnesota, USA), temperate (Washington and Idaho, USA), and tropical (Puerto Rico) forest types. They conclude that moisture condition is an important control over wood decomposition over broad climate gradients, and that such relationship can be non-linear. Further, that the presence of a particular group of organism (termites) can significantly alter the decay rates of wood more than what might be predicted based on climatic factors alone suggests biotic controls on wood decay might be more important predictors of wood decay in tropical regions (rather than abiotic constraints).

\section{CONCLUDING REMARKS}

The results of these studies highlight the important role soil organisms play in soil formation and soil organic matter dynamics. Decaying organic materials have a significant effect on soils underneath which could help explain the spatial heterogeneity in soil properties, such as nutrient availability. As global changes can alter both climate and organic matter inputs, associated shifts in the community structure of soil and litter invertebrates can have significant effects on decomposition rates and nutrient cycling (Shiels et al., 2015). Recent advancements in the study of soil microbial-faunal interactions have opened a new dimension in the understanding of soil biology and ecosystem ecology on the island (e.g., Richardson et al., 2010; González et al., 2014; 
Shiels et al., 2014, 2015). Yet there is still a need for comprehensive and manipulative field studies that try to tease apart the distinct effect of soil organisms (González, 2002). This is not an easy task, for the interactions of abundance, diversity, activity and functionality of soil organisms are at play (González, 2002). Still, it is important to further our understanding of the biocomplexity of soil invertebrate activities and interactions as they can have profound effects on the functioning of systems around the globe.

\section{ACKNOWLEDGMENTS}

Most of this research and the writing of this manuscript was performed under grants DEB-0218039 and 1239764 from the National Science Foundation to the Institute of Tropical Ecosystem Studies, University of Puerto Rico, and the United States Department of Agriculture, Forest Service, International Institute of Tropical Forestry as part of the Long-Term Ecological Research Program in the Luquillo Experimental Forest. Additional support to GG was provided by the Luquillo Critical Zone Observatory (EAR-1331841), University of Puerto Rico, and the Forest Service (U.S. Department of Agriculture). We thank Drs. Kevin D. Carlin, William A. Gould, D. Jean Lodge, Ariel E. Lugo and Frank $\mathrm{H}$. Wadsworth for commenting on an earlier version of this manuscript.

\section{LITERATURE CITED}

Barberena-Arias, M. F., 2008. Single tree species effects on temperature, nutrients and arthropod diversity in litter and humus in the Guánica dry forest. Ph.D. Diss. University of Puerto Rico.

Barberena-Arias, M. F., 2000. A comparison of litter macroarthropods diversity among three habitats in Mona Island. Acta Científica 14(1-2): 51-59.

Barberena-Arias, M. F. and T. M. Aide, 2003. Species diversity and trophic composition of litter insects during plant secondary succession. Caribb. J. Sci. 39(2): 161-169.

Barberena-Arias, M. F. and T. M. Aide, 2002. Variation in species and trophic composition of insect communities in Puerto Rico. Biotropica 34(3): 357-367.

Barberena-Arias, M. F., G. González and E. Cuevas, 2012a. Quantifying variation of soil arthropods using different sampling protocols: is diversity affected? pp 51-92, In: P. Sudarshana, M. Nageswara-Rao and J.R. Soneji (eds.). Tropical Forests. 388 pp.

Barberena-Arias, M. F., J. Ortiz-Zayas, C. Abad, G. Almodóvar, E. López, M. Rodríguez, M. Samó, G. Dávila and L. Troche, 2012b. Comparación de la fauna de artrópodos terrestres entre pastizales y bosques dominados por el tulipán africano (Spathodea campanulata), en tres zonas del carso norteño en Puerto Rico. Acta Cientifica 26(13): 68-79.

Birdsey, R. A. and P. L. Weaver, 1987. Forest area trends in Puerto Rico. Res. Note. SO331. New Orleans, LA: U.S. Department of Agriculture, Forest Service, Southern Forest Experiment Station. 5 p.

Bloomfield, J. K, K. A. Vogt and D. J. Vogt, 1993. Decay rate and substrate quality of fine roots and foliage of two tropical species in the Luquillo Experimental Forest, Puerto Rico. Plant Soil 150: 233-245. 
Coleman, D. C. and D. A. Crossley Jr., 1996. Fundamentals of Soil Ecology. New York: Academic Press.

Franco, P. A., P. L. Weaver and S. Eggen-McIntosh, 1997. Forest resources of Puerto Rico, 1990. Ashville, NC: U.S. Department of Agriculture, Forest Service, Southern Research Station. 45 p.

Galanes, I. T. and J. R. Thomlinson, 2011. Soil millipede diversity in tropical forest patches and its relation to landscape structure in northeastern Puerto Rico. Biodivers. Conserv. 20(13): 2967-2980.

Galanes, I. T. and J. R. Thomlinson, 2009. Relationships between spatial configuration of tropical forest patches and woody plant diversity in northeastern Puerto Rico. Plant Ecol 201: 101-113.

González, G., 2002. Soil organisms and litter decomposition. Pp. 315-329. In: Modern Trends in Applied Terrestrial Ecology. R.S. Ambasht and N.K. Ambasht (eds). Kluwer Academic / Plenum Publishers, UK.

González, G., W. A. Gould, A. T. Hudak and T. Hollingsworth, 2008. Decay of aspen (Populus tremuloides Michx.) wood in moist and dry boreal, temperate and tropical forest fragments. Ambio 37(7-8): 588-597.

González, G., R. Ley, S. K. Schmidt, X. Zou and T. R. Seastedt, 2001. Soil ecological interactions: comparisons between tropical and subalpine forests. Oecologia 128: 549-556.

González, G., D. J. Lodge, B. A. Richardson and M. J. Richardson, 2014. A canopy trimming experiment in Puerto Rico: the response of litter decomposition and nutrient release to canopy opening and debris deposition in a subtropical wet forest. For. Ecol. Manage. 332: 32-46.

González, G. and M. M. Luce, 2013. Woody debris characterization along an elevation gradient in northeastern Puerto Rico. Ecological Bulletins 54: 181-193.

González, G., C. M. Murphy and J. Belén, 2012. Direct and Indirect Effects of Millipedes on the Decay of Litter of Varying Lignin Content, Tropical Forests, Padmini Sudarshana (eds). ISBN: 978-953- 51-0255-7, 37-50. InTech.

González, G. and T. R. Seastedt, 2001. Soil fauna and plant litter decomposition in tropical and subalpine forests. Ecology 82(4): 955-964.

González, G. and T. R. Seastedt, 2000. Comparison of the abundance and composition of litter fauna in tropical and subalpine forests. Pedobiologia 44: 545-555.

González, G. and X. Zou, 1999. Earthworm influence on $\mathrm{N}$ availability and the growth of Cecropia schreberiana in tropical pasture and forest soils. Pedobiologia 43 (6): 824-829.

González, G., X. Zou and S. Borges, 1996. Earthworm abundance and species composition in abandoned tropical croplands: Comparisons of tree plantations and secondary forests. Pedobiologia 40: 385-391.

Gould, W. A., C. Alarcón, B. Fevold, M. E. Jiménez, S. Martinuzzi, G. Potts, M. Quiñones, M. Solórzano and E. Ventosa, 2008. The Puerto Rico Gap Analysis Project. Volume 1: Land cover, vertebrate species distributions, and land stewardship. Gen. Tech. Rep. IITF-GTR-39. Río Piedras, PR: U.S. Department of Agriculture, Forest Service, International Institute of Tropical Forestry. $165 \mathrm{p}$.

Hansen, R.A., 1999. Red oak litter promotes a microarthropod functional group that accelerates its decomposition. Plant Soil 209:37-45.

Helmer, E. H., O. M. Ramos-González, T. del M. López, M. Quiñonez and W. Díaz, 2002. Mapping the forest type and land cover of Puerto Rico, a component of the Caribbean biodiversity hotspot. Caribb. J. Sci. 38(3-4): 165-183.

Heneghan, L., D. C. Coleman, X. Zou, D. A. Crossley and B. L. Haines, 1998. Soil microarthropod community structure and litter decomposition dynamics: A study of tropical and temperate sites. App. Soil Ecol. 9(1-3): 33-38.

Heneghan, L., D. C. Coleman, X. Zou, D. A. Crossley and B. L. Haines, 1999. Soil microarthropod contributions to decomposition dynamics: Tropical-temperate comparisons of a single substrate. Ecology 80(6): 1873-1882.

Huang, C. Y., G. González and P. F. Hendrix, 2006. The re-colonization ability of a native earthworm, Estherella spp., in forests and pastures in Puerto Rico. Caribb. J. Sci. 42(3): 386-396. 
Huang, C.-Y., G. González and P. Hendrix, 2016. Resource utilization by native and exotic earthworms and their impacts on soil carbon and nitrogen dynamies in Puerto Rican soils. Forests 7(11): 277.

Irmler, U., 2000. Changes in the fauna and its contribution to mass loss and $\mathrm{N}$ release during leaf litter decomposition in two deciduous forests. Pedobiologia 37: 379-384.

La Caro, F. and R. L. Rudd, 1985. Leaf litter disappearance rates in Puerto Rican montane rain Forest. Biotropica 17: 269-276.

Lodge, D. J., W. H. McDowell, J. Macy, S. K. Ward, R. Leisso, K. Claudio-Campos and K. Kuhnert, 2008. Distribution and role of matforming saprobic basidiomycetes in a tropical forest. In: Boddy, L., and Frankland J.C. (eds). Ecology of saprobic basidiomycetes. Elsevier, Amsterdam, pp 195-208.

Murdoch, W. W., F. C. Evans and C. H. Peterson, 1972. Diversity and patterns in plants and insects. Ecology 53(5): 819-828.

Murphy, C. M., G. González and J. Belén, 2008. Ordinal abundance and richness of millipedes (Arthropoda: Diplopoda) in a subtropical wet forest in Puerto Rico. Acta Cientifica 22(1-3): 57-65.

Odum, H. T., W. Abbott, R. K. Selander, F. B. Golley and R. F. Wilson, 1970. Estimates of chlorophyll and biomass of the tabonuco forest of Puerto Rico. Pages I3-I19 in H. T. Odum and R. F. Pigeon (eds). A tropical rain forest: A study of irradiation and ecology at El Verde, Puerto Rico. Oak Ridge, TN: U.U. Atomic Energy Commission, Division of Technical Information.

Osorio-Pérez, K., M. F. Barberena-Arias and T. M. Aide, 2007. Changes in ant species richness and composition during plant secondary succession in Puerto Rico. Caribb. J. Sci. 43(2): 244-253.

Pfeiffer, W. J., 1996. Litter invertebrates. In: Reagan, D. P. and Waide, R. B. (eds.). The food web of a tropical rain forest. Univ. Chicago Press, pp. 137-181.

Richardson, B. A. and M. J. Richardson, 2013. Litter-based invertebrate communities in forest floor and bromeliad microcosms along an elevational gradient in Puerto Rico. Ecological Bulletins 54: 101-115.

Richardson, B. A., M. J. Richardson, G. González, A. B. Shiels and D. S. Srivastava, 2010. A Canopy Trimming Experiment in Puerto Rico: The Response of Litter Invertebrate Communities to Canopy Loss and Debris Deposition in a Tropical Forest Subject to Hurricanes. Ecosystems 3: 286-301.

Richardson, B. A., M. J. Richardson and F. N. Soto-Adames, 2005. Separating the effects of forest type and elevation on the diversity of litter invertebrate communities in a humid tropical forest in Puerto Rico. J. Anim. Ecol. 74: 926-936.

Ruan, H., Y. Li and X. Zou, 2005. Soil communities and plant litter decomposition as influenced by forest debris: Variation across tropical riparian and upland sites. Pediobiologia 49: 529-538.

Sánchez-de León, Y. and X. Zou, 2004. Plant influences on native and exotic earthworms during secondary succession in old tropical pastures. Pedobiologia 48(3): 215-226.

Santana, M., D. J. Lodge and P. Lebow, 2005. Relationships of host recurrence in fungi to tropical leaf decomposition. Pedobiologia 49:549-564.

Schowalter, T. D., S. J. Fonte, J. Geaghan and J. Wang, 2011. Effects of manipulated herbivore inputs on nutrient flux and decomposition in a tropical rainforest in Puerto Rico. Oecologia 167(4): 1141-1149.

Seastedt, T. R. 1984. The role of microarthropods in decomposition and mineralization processes. Annual Review of Entomology 29: 25-46.

Shiels, A., G. González, D. J. Lodge, M. R. Willig and J. K. Zimmerman, 2015. Cascading effects of canopy opening and debris deposition from a large-scale hurricane experiment in a tropical rainforest. Bioscience $65(9): 871-881$.

Shiels, A.B., G. González and M.R. Willig, 2014. Responses to canopy loss and debris deposition in a tropical forest ecosystem: Synthesis from an experimental manipulation simulating effects of hurricane disturbance. For. Ecol. Manage. 332: 124-133.

Sullivan, N. H., W. B. Bowden and W. H. McDowell, 1999. Short-term disappearance of foliar litter in three species before and after a hurricane. Biotropica 31: 382-393. 
Swift, M. J., O. W. Heal and J. M. Anderson, 1979. Decomposition in terrestrial ecosystems. Blackwell Scientific Publications, London, UK.

Torres, J. A. and G. González, 2005. Wood decomposition of Cyrilla racemiflora (Cyrillaceae) in Puerto Rican dry and wet forests: A 13-year Case Study. Biotropica 37: 452-456.

Wall, D. H., G. González and B. Simmons, 2011. Seasonally dry forest soil biodiversity and functioning. Pp. 61-70. In: Seasonally dry tropics forests, ecology and conservation. R. Dirzo, H. S. Young, H. A. Mooney, and G. Ceballos, (eds). Island Press, Washington, D.C.

Warren, M., 2000. Stand characteristics of three forest types on Mona Island: Composition, structure and biomass distribution. Acta Cientifica 14(1-2): 3-12.

Yang, X., M. Warren and X. Zou, 2007. Fertilization responses of soil litter fauna and litter quantity, quality, and turnover in low and high elevation forests of Puerto Rico. App. Soil Eco. 37(1-2): 63-71.

Zou, X. and G. González, 1997. Changes in earthworm density and community structure during secondary succession in abandoned tropical pastures. Soil Biol. Biochem. 29(3-4): 627-629. 